\title{
Unir e dividir: as controvérsias em torno da organização político-administrativa do território na Província de Minas Gerais (1825-1834)
}

\section{To unite and to divide: the controversies around the political- administrative organization of the territory in the Province of Minas Gerais (1825-1834)}

\author{
Renata Silva Fernandes*
}

\begin{abstract}
Resumo
Neste artigo, propomos uma análise da organização político-administrativa do território na província de Minas Gerais entre 1825 e 1834, considerando, sobretudo, a divisão das unidades administrativas locais básicas, as municipalidades. Para tanto, utilizaremos os debates e resoluções sobre o assunto engendrados no âmbito do executivo provincial (Presidentes e Conselho de Governo) e do Conselho Geral, instituições provinciais criadas no período pós-emancipação política do Brasil que se viram encarregadas de mediar uma série de tensões advindas de antigas e novas demandas relativas à organização interna do território.
\end{abstract}

Palavras-Chave: Território; Minas Gerais; Conselho Geral de Província; Conselho da Presidência; Império do Brasil.

\begin{abstract}
In this article, we intend to analyze the political-administrative organization of the territory in the province of Minas Gerais between 1825 and 1834 focusing primarily on the division of the most simple administrative units, that is, the municipalities. In order to do so, we take into consideration the debates and resolutions produced by the Council of Government and the General Council, provincial institutions created in the aftermath of Brazil's political emancipation with the purpose of (among other activies) mediating the tensions arose by the old and new needs regarding the organization of the territory.
\end{abstract}

Keywords: Territory; Minas Gerais; General Council of the Province; Presidential Council; The Empire of Brazil.

*Doutoranda no Programa de Pós-Graduação em História da Universidade Federal de Juiz de Fora. Bolsista CAPES.E-mail:renatacjm@gmail.com 
Pelas três horas da tarde do dia 7 de setembro de 1833, os Povos da Freguesia de Camanducaia reuniram-se para celebrar o aniversário de "nossa feliz independência". Após o ato religioso, aglomerados no largo da Igreja Matriz, o padre Francisco de Paula Toledo, vigário encomendado da freguesia, entregou ao juiz de paz de Camanducaia, Pedro de Alcântara e Silva, uma representação dos Povos de vários distritos para que naquele dia fosse Camanducaia autoproclamada vila da província de Minas Gerais. Após meditações feitas pelas autoridades presentes,

os ditos cidadãos entraram logo a dar vivas a Santa Religião, a Independência do Império, a sua majestade o Senhor D. Pedro II, a Assembleia Geral Legislativa, a Regência, a nova vila de Camanducaia e a sua independência da vila de Pouso Alegre, e que imediatamente se levantasse o pelourinho o qual eles cidadãos apareceram com ele pronto e o fizeram colocar no Largo do Rosário onde os ditos juízes marcaram como mais próprio lugar, e o fizeram com toda a solenidade que antes se achavam. ${ }^{1}$

Os cidadãos de Camanducaia, "indispensavelmente obrigados pelo seu dever mais sagrado de tratar da sua ventura e do aperfeiçoamento da associação do seu país" ${ }^{2}$, desde muito recorriam pela via peticionária às instituições provinciais de Minas Gerais para serem alçados à condição de vila.

No entanto, naquele 7 de setembro de 1833, após uma longa espera dentro dos trâmites previstos pela legislação imperial - que delongara em anos a ansiada criação, já proposta pelo Conselho Geral mineiro ao corpo legislativo - a freguesia de Camanducaia declarava sua própria independência, exigindo que cessasse toda jurisdição da vila de Pouso Alegre e que o governo provincial e a Regência em nome do Imperador decidissem sobre o assunto. À frente do movimento, encontravam-se articulados alguns dos principais nomes da elite política local da freguesia e dos distritos adjacentes de Santa Rita, Cambuí e Capivari, representados pelas figuras dos respectivos juízes de paz e de lideranças religiosas. ${ }^{3}$

As justificativas que apresentavam para a urgência que levara à autoproclamação centravam-se, sobretudo, nos "perigos" a que estavam sujeitos os habitantes da localidade. As principais queixas vertiam-se, nesse sentido, para acusações de arbitrariedades na administração da justiça cometidas pela

\footnotetext{
${ }^{1}$ Apud SENNA, Nelson de (dir.). Anuário de Minas Gerais: obra versando sobre estatística, crônica, história, corografia, finanças, variedades, biografias, literatura, indicações. Ano V. Belo Horizonte: Imprensa Oficial, 1913. p. 476.

${ }^{2}$ Arquivo Público Mineiro (APM). Fundo Conselho Geral de Província (CGP). Série 1: Correspondência Recebida, Subsérie 4: Diversos (CGP14), CX. 01.
}

${ }^{3}$ O RECOPILADOR Mineiro, n. 93, 4 de janeiro de 1834. 
vila de Pouso Alegre, termo ao qual haviam sido incorporados em 1831 por projeto convertido em decreto do Conselho Geral mineiro, medida que, no entanto, resultara em uma intensificação dos conflitos entre as elites políticas daquela região, agravados, ainda, pelas desordens políticas verificadas na província de Minas Gerais naquele conturbado ano de $1833 .{ }^{4}$

Em meio a novas e velhas concepções sobre o território e o poder, o movimento valia-se de múltiplos símbolos de legitimidade que perpassavam desde a escolha cuidadosa da data, que fazia coincidir a "feliz independência" do Brasil, que se libertara do "despotismo" de Portugal, com a "feliz independência" de Camanducaia, livre então das "arbitrariedades" da Vila de Pouso Alegre, até a instalação de um pelourinho, tradicional representante da autonomia dos concelhos e parte obrigatória do ritual de instituição de vilas no Império Português.

O episódio, que invertia a ordem da cadeia governativa instituída no Império, o que o dotava de um caráter potencialmente radical, é indicativo de algumas das tensões e controvérsias em torno da organização política do território no período que se seguiu à emancipação política do Brasil, bem como de alguns dos desafios defrontados na instituição de um governo provincial em Minas Gerais em sua tarefa de efetivação de transformações político-administrativas que coadunassem com a ordem que se pretendia impor.

A organização e divisão das unidades base da administração imperial, as municipalidades, vinculavam-se diretamente à questão fiscal, aos processos de ocupação e povoamento, a interesses de grupos de poder, mas também às possibilidades de efetiva implementação da normatização legal, de afirmação da autoridade e de viabilização da unidade e estabilidade do "novo" Império, que, herdado, trazia consigo uma contiguidade histórica de práticas, instituições, valores, territórios e conformações identitárias. Não sem motivos, a (re)organização das circunscrições municipais converter-se-ia, na província de Minas Gerais, precisamente, em uma coordenada de ação privilegiada dos Presidentes em Conselho de Governo ${ }^{5}$ e do Conselho Geral ${ }^{6}$,

\footnotetext{
${ }^{4}$ Em especial, em meio aos conflitos de jurisdição engendrados pela Sedição de 1833, a da nomeação, considerada ilegal pelos camanducaienses, do capitão José Francisco Pereira Filho como juiz ordinário da vila de Pouso Alegre.

${ }^{5} \mathrm{O}$ decreto da Assembleia Constituinte de 20 de outubro de 1823 estabelecia que as províncias do Império do Brasil seriam governadas por um Presidente, chefe do executivo provincial, nomeado e amovível pelo Imperador. Os Presidentes seriam auxiliados, nessa tarefa, por um Conselho de Governo eletivo, composto por seis membros eleitos pelos habitantes das províncias, que desempenhariam atribuições consultivas e deliberativas. BRASIL. Decreto de 20 de outubro de 1823. Colecção das leis da Assembleia Constituinte e Legislativa do Império do Brasil. Rio de Janeiro: Imprensa Nacional, 1887. Os Conselhos de Governo funcionaram até 1834, quando foram extintos pelo Regimento dos Presidentes de província.

${ }^{6}$ A Constituição Política do Império do Brasil de 1824 determinou o estabelecimento de outro órgão colegial
} 
instituições político-administrativas criadas no período pós-emancipação que seriam encarregadas, dentre outras coisas, de propor sobre a divisão física, civil e eclesiástica, de seus respectivos territórios.

\section{As necessidades da vasta província de Minas Gerais}

Como é bem sabido, a organização político-administrativa do território resulta de construções políticas, sociais e simbólicas plurais que se refletem nas formas de gerência do espaço pelo poder e na sua percepção e apropriação pelas práticas humanas. ${ }^{\text {? }}$

No Império Português do Antigo Regime, a organização do território tendia a observar as divisões tradicionais ou "naturais" do espaço. O território político representava, antes de mais nada, o espaço habitado pela comunidade que vivia sob um mesmo estatuto e que reconhecia uma mesma autoridade, a "unidade tradicional". ${ }^{8}$ Partindo-se do princípio de existência de uma constituição natural da sociedade, que deveria ser, na medida do possível, preservada pelo poder, que tinha a função de assegurar o funcionamento harmônico dos corpos sociais e territoriais exercendo Justiça, a organização político-administrativa do espaço, pela mútua vinculação entre território e jurisdição, era rígida. Qualquer alteração era vista como um atentado à integridade do território e sua jurisdição, já que as unidades como as municipalidades detinham direitos incorporados na divisão do território a seus termos que, assim, eram irredutíveis. ${ }^{9}$

Com a emergência de novos paradigmas políticos vinculados à ilustração em meados do século XVIII, essa percepção do território e de sua organização começaram a se alterar. A progressiva consolidação de princípios como o da razão de Estado aproximou a prática política de uma "administração ativa”, que buscava ordenar e racionalizar, cada vez mais, a sociedade e o poder $^{10}$, o que demandava novas soluções espaciais. 0 equilíbrio populacional

eletivo nas províncias, os Conselhos Gerais de província, criados como garantia do "direito de intervir todo cidadão nos negócios de sua província e que são imediatamente relativos a seus interesses peculiares". BRASIL. Constituição Política do Império do Brasil de 25 de março de 1824. Rio de Janeiro, 1824. Os Conselhos Gerais foram substituídos pelas Assembleias Legislativas provinciais pelo Ato Adicional de 1834.

${ }^{7}$ Sobre o assunto ver: SILVA, Ana Cristina Nogueira. 0 modelo espacial do Estado Moderno: reorganização territorial em Portugal no final do Antigo Regime. Lisboa: Estampa, 1998.

${ }^{8}$ HESPANHA, António Manuel. Às vésperas do Leviathan. Instituições e Poder político. Portugal século XVII. Coimbra: Almedina, 1994. p. 89.

${ }^{9}$ SILVA, Ana Cristina Nogueira, op. cit. p. 49-53; FONSECA, Cláudia Damasceno. Arraiais e vilas d'El Rei: espaço e poder nas Minas setecentistas. Belo Horizonte: Editora UFMG, 2011. p. 300.

${ }^{10}$ MATTOSO, José. História de Portugal: o Antigo Regime. Lisboa: Editorial Estampa, 1998. V. 4. p. 143. 
e a extensão, a centralidade das sedes administrativas e suas distâncias em relação às outras partes do território, a homogeneidade jurídica, a conveniência econômica e administrativa, dentre outros elementos, despontavam como critérios de divisão territorial pelo poder, os quais, no entanto, coexistiriam, por muito tempo, com outros, mais tradicionais. ${ }^{11}$

Na esteira de semelhantes preocupações que passaram, desde então, a ocupar um lugar central nos debates relativos aos imperativos governativos, mas também diante dos desafios concretos, com a emancipação política do Brasil, de instituição de um novo ordenamento - ao menos de acordo com determinado projeto pretensamente pautado na divisão de poderes, na unidade e soberania nacional, e na racionalização da arte de governar - a (re) organização interna do território converteu-se, em Minas Gerais, em uma das principais coordenadas de ação dos Presidentes em Conselho de Governo e do Conselho Geral da província nos anos que se seguiram a Independência. ${ }^{12}$ Como indicava um membro do Conselho Geral, em um artigo em defesa da criação de novas circunscrições municipais: ${ }^{13}$

A província de Minas Gerais contém cento e dez mil fogos, e dando por um senso médio a cada um, nove habitantes, teremos em resultado uma população de novecentos e noventa mil habitantes, dos quais um terço pelo menos se reputa ser de escravos; logo seiscentos e sessenta mil habitantes são livres. Estes se acham disseminados por uma superfície de mais de 40 mil léguas quadradas, segundo alguns geógrafos estrangeiros, que viajaram o Brasil, e segundo outros de 28 a 30 mil; seja o que for, o certo é que ela tem na sua maior latitude leste a

\footnotetext{
${ }^{11}$ Cf. SILVA, Ana Cristina Nogueira da, op. cit; FONSECA, Cláudia Damasceno, op. cit.

${ }^{12}$ É preciso destacar que tanto os Presidentes em Conselho de Governo como os Conselhos Gerais de província tiveram, em momentos distintos, ingerência propositiva ou deliberativa nas definições das divisões civis e eclesiásticas internas das províncias. Sobre as circunscrições municipais, a lei de 20 de outubro de 1823 estabelecia que os Presidentes em Conselho de Governo deveriam propor sobre o estabelecimento de novas câmaras. Cf. BRASIL. Decreto de 20 de outubro de 1823, op. cit. Com a criação dos Conselhos Gerais pela Constituição de 1824, encarregados de "propor, discutir e deliberar" sobre os negócios mais interessantes de suas províncias, e, concretamente, a partir de 1828, quando começaram a ser instalados nas províncias do Império (com a publicação do regimento que regulamentava seus trabalhos), essas instituições é que passaram a ser as encarregadas de remeter, ao corpo legislativo, projetos relativos à criação de vilas. Já com o Código do Processo de 1832 os Presidentes em Conselho de Governo foram autorizados a elaborar uma nova divisão dos termos e comarcas de suas respectivas províncias. Cf. BRASIL. Lei de 29 de novembro de 1832. Colleção das Leis do Império do Brazil de 1832: Atos do Poder Legislativo. Rio de Janeiro: Typographia Nacional, 1874.

${ }^{13} \mathrm{O}$ autor do mencionado artigo, assinado como "um membro do Conselho Geral" era, possivelmente, Baptista Caetano de Almeida, redator do periódico Astro de Minas e conselheiro geral e de governo. Como deputado pela província de Minas Gerais na Assembleia Geral, Baptista Caetano de Almeida também discorreu em termos similares na Câmara dos Deputados sobre a divisão dos termos da província mineira.
} 
oeste 240 léguas, e de longitude de Norte a Sul 200 léguas; e nesta vastidão de território se contavam apenas dezesseis termos municipais [...]. ${ }^{14}$

A organização herdada do passado colonial - feita, como asseverava um membro do Conselho Geral, "não com conhecimento de causa, e nem mesmo com o fim de ser útil a população da Província e sim [...] a aprazimento dos mandões, que nos dominaram por longos anos"15 - não satisfazia, nesses termos, "as necessidades dos povos" da província e, tampouco, os princípios de razão política e boa governabilidade. Os dilemas que se impunham, nessa direção, davam-se, sobretudo, nas possibilidades de efetiva atuação das câmaras municipais e das autoridades de justiça ${ }^{16} \mathrm{e}$, em decorrência, do próprio controle a ser exercido pelas instituições provinciais - e pelo governo imperial - sobre esse grande território e população.

Associadas a uma desconfiança em relação aos corpos municipais enquanto agentes de reivindicações localistas ${ }^{17} \mathrm{e}$ a ânsia pelo enquadramento das diferentes instâncias à dinâmica do "novo" Estado, as câmaras municipais eram, precisamente, um dos principais alvos das críticas elaboradas pelos conselheiros mineiros.

Em um primeiro plano, situavam-se questionamentos feitos à própria organização e procedimentos adotados pelas administrações municipais da província. Nas instituições provinciais mineiras não eram poupadas críticas, principalmente, à administração das receitas e despesas municipais. Como indicava o conselheiro de governo Theotônio Álvares de Oliveira Maciel, ela seria marcada por "desmazelos" e "egoísmo" dos vereadores, que, desprezando "leis positivas" e iludindo os corregedores, procediam com gastos abusivos em objetos que não traziam benefícios a seus concelhos, como as próprias propinas, as altas quantias despendidas com fogos de artifício, festividades religiosas e luminárias. ${ }^{18}$ Nas câmaras, em seus "moldes antigos", prevaleceria, deste modo, o luxo e os particulares interesses em detrimento do "bem públi-

\footnotetext{
${ }^{14}$ ASTRO de Minas, n. 683, op. cit.

${ }^{15}$ Ibidem.

${ }^{16}$ APM. Seção Provincial (SP). Registro de atas do Conselho do Governo, SP 33.

${ }^{17}$ Sérgio Buarque de Holanda já afirmava que "a decadência das instituições municipais entre nós insere-se assim no quadro mais largo da liquidação da herança colonial [...]”. Em sua opinião, independente das divergências sobre a amplitude da autonomia e das atribuições exercidas pelas câmaras, "o abatimento a que, depois da Independência e principalmente depois de 1834 se reduziu o sistema municipal, faz realçar, pelo contraste, o papel que entre nós ele assumira em épocas anteriores". HOLANDA, Sérgio Buarque de. A herança colonial - sua desagregação. In: HOLANDA, Sérgio Buarque de (org.). História Geral da Civilização Brasileira. 6a ed. São Paulo: Difel, 1985. t. II, v . 1. p. 26.
}

${ }^{18}$ MINAS GERAIS. Diários do Conselho de Governo da Província de Minas Gerais de 1825, ed. 16. 
co", críticas que não se limitavam, ademais, à administração financeira dos municípios, abrangendo tudo aquilo que se encontrava sob suas competências.

Esse quadro agravava-se ainda mais, conforme essa perspectiva, nos lugares menos centrais e mais distantes das sedes concelhias, já que os benefícios que deveriam advir das administrações municipais restringir-se-iam apenas às cabeças dos termos, ficando as demais partes preteridas ou em completo abandono. As câmaras não podiam cuidar da feitura e manutenção das estradas, pontes, canais, calçadas, aquedutos e chafarizes, não conseguiam garantir a observância das posturas ou acesso a seus oficiais (assim como as autoridades judiciais) e, de maneira geral, a arrecadação de suas receitas era defeituosa e a aplicação de suas despesas, desigual.

Essas problemáticas, no parecer dos conselheiros mineiros, seriam parcialmente resolvidas com uma necessária reformulação da organização e competência das câmaras municipais - levada a cabo pela considerada "muito providente" lei de $1^{\circ}$ de outubro de 1828 - e com uma constante fiscalização sobre suas atuações a ser desempenhada por essas instituições provinciais que, desde suas criações, foram progressivamente encarregadas de tutelar a atuação de semelhantes organismos. ${ }^{19}$

Os Conselho de Governo e, posteriormente, o Conselho Geral, buscariam efetivar, dentro dos limites de suas atribuições, o enquadramento das "antigas câmaras" da província - que eram "reduzidas unicamente a fazer festas" - como "câmaras constitucionais", como destacavam os conselheiros gerais integrantes da Comissão de Posturas na sessão de 14 de janeiro de $1830 .{ }^{20}$ Para tanto, essas instituições provinciais, especialmente o Conselho Geral, ocupariam parte significativa de suas sessões verificando a legalidade dos livros de contas das câmaras, fiscalizando a feitura de obras - objeto considerado de primeira necessidade e um dos principais deveres das muni-

\footnotetext{
${ }^{19} \mathrm{Assim}$, por exemplo, a lei de 20 de outubro de 1823 determinava que competia aos Presidentes em Conselho de Governo a análise das contas de receita e despesa das câmaras municipais, depois de fiscalizadas pelo corregedor da respectiva comarca. Ver: BRASIL. Decreto de 20 de outubro de 1823, op. cit. Por seu turno, a lei de $1^{\circ}$ de outubro de 1828 , que dava regimento às câmaras municipais, determinou que competia aos Conselhos Gerais de província a aprovação das posturas elaboradas pelas câmaras bem como a recepção dos recursos dos cidadãos que por elas se sentissem agravados. Também os incumbiu de verificar a legalidade dos livros de receita e despesa municipal, de aprovar gratificações e ordenados arbitrados a alguns dos empregados camarários, autorizar a venda, aforamento ou troca de bens imóveis, assim como deferir os planos e condições de obras de grande importância. Ver: BRASIL. Lei de $1^{\circ}$ de outubro de 1828. Collecção das Leis do Império do Brazil de 1828. Rio de Janeiro: Typografia Nacional, 1878.

${ }^{20}$ APM. CGP. Registro das atas do Conselho Geral da Província, CGP 01. A Comissão era composta pelos conselheiros Bernardo Pereira de Vasconcellos, João Baptista Figueiredo, Theotônio Alvares de Oliveira Maciel, Manoel José Pires da Silva Pontes e Joaquim José da Silva Brandão.
} 
cipalidade ${ }^{21}$-, sugerindo e arbitrando medidas para uma boa arrecadação de tributos e criando regulamentos e metodologias para registro e ordenamento das receitas e despesas. ${ }^{22}$

Empenho semelhante seria empregado na análise e correção das posturas elaboradas pelas municipalidades, que, com seus efeitos regulamentadores e disciplinadores de imposição de condutas, deveriam ser as mais uniformes possíveis para "facilitar, e propagar por toda a província a maior parte dos deveres municipais". ${ }^{23}$ As câmaras eram as encarregadas de velar, sob a tutela das instituições provinciais, por tudo aquilo que dizia respeito ao controle e normatização da população compreendida em seus termos. Nos domínios de um Estado que se pretendia Nação, essa tradicional função adquiriria novos contornos, e renovada importância seria dada àquilo que genericamente se denominava de economia e polícia ${ }^{24}$ : a regulamentação econômica e a feitura de obras, a saúde, higiene e salubridade, a tutela dos desvalidos e enfermos, a educação e a moral públicas, as celebrações e, em geral, o controle dos grupos sociais marginalizados, a garantia da segurança particular e pública e a manutenção da ordem nas povoações. ${ }^{25}$

Mas no parecer dos conselheiros mineiros, para que essas reformulações obtivessem o êxito esperado, seriam igualmente necessárias alterações nas próprias concretudes espaciais dos termos da província. As câmaras municipais, para o bom desempenho de suas importantes atribuições - e para que as instituições provinciais, ainda que não sem tensões e conflitos, fizessem observar efetivamente suas determinações - deveriam "compreender em sua administração menor extensão de territórios do que atualmente compreendem os termos"26: a "desmedida extensão" 27 , as "longitudes" e a "má divisão"28 levavam à inexecução das leis em prejuízo do Estado e de sua população, que

\footnotetext{
${ }^{21}$ MINAS GERAIS. Collecção dos Diarios do Concelho Geral da Provincia de Minas Geraes. Imperial Cidade de Ouro Preto: Typografia do Universal, 1830-1832. p. 71-93.

${ }^{22}$ APM. CGP. Registro das propostas do Conselho Geral da Província, CGP 04.

${ }^{23}$ APM. CGP 01, op. cit.

${ }^{24}$ Sobre o assunto, ver: CATROGA, Fernando. A geografia dos afectos pátrios: as reformas político-administrativas, séculos XIX-XX. Coimbra: Alamedina, 2013.

${ }^{25}$ Sobre a atuação do Conselho Geral na província de Minas Gerais e as tensões em torno da instalação da esfera pública de poder na província ver: SILVA, Ana Rosa Cloclet da. Império, província e periferia. In: Revista do Arquivo Público Mineiro. Belo Horizonte, ano L, n. 2, jul./dez. 2014.

${ }^{26}$ APM. CGP 04, op. cit.

${ }^{27}$ MINAS GERAIS. Diários do Conselho de Governo da Província de Minas Gerais de 1825, op. cit., n. 16.

${ }^{28}$ ASTRO de Minas, n. 683, op. cit.
} 
manifestava, nesse sentido, contínuas e "justas" reclamações, demandando a criação de novas vilas.

A "boa divisão física do território" da Nação, sinal da "boa ordem dos negócios" e necessária para a "boa execução das leis [...]”29, é que que garantiria, por essa perspectiva, que o "gérmen da vitalidade patriótica, que hoje nos lugares remotos se achava sem algum estímulo para brilhar na órbita civil e política da Sociedade" fosse vivificado..$^{30}$ Ela era, assim, antes de mais nada, necessária para estreitar - e atar em bases sólidas - os laços entre as periferias e o centro, assegurando a própria legitimidade do Estado (e sua capacidade de atuação) e os princípios em que esse buscava sustentar-se.

Para superar o parcelamento político-administrativo característico do Antigo Regime Português, a redistribuição territorial do poder municipal, ao menos discursivamente, deveria atender a critérios que coadunavam com a racionalização, regulamentação e uniformização, dispositivos que se impunham, progressivamente, como necessários à arte de governar. ${ }^{31}$ Precisamente, a hierarquização dos espaços deveria se basear na densidade populacional, na extensão territorial e nas distâncias existentes entre as sedes administrativas e as demais áreas dos termos ou entre aquelas e os municípios circunvizinhos.

Para atender a esses princípios, o Conselho de Governo de Minas Gerais, como uma de suas primeiras iniciativas, ainda em 1825, procedeu à elaboração de uma grande proposta, a ser remetida ao governo imperial, de nova organização geral da província, que instituía critérios objetivos para a constituição das vilas e freguesias mineiras. Em suas diretrizes, que privilegiavam a questão do agrupamento demográfico, determinou-se que as vilas nas comarcas de Ouro Preto, Rio das Velhas, Rio das Mortes e Serro Frio deveriam ser compostas por quatorze mil almas, enquanto as de Paracatu, região com menor população, por seis a dez mil almas..$^{32}$ Com base em um mapa detalhado,

\footnotetext{
${ }^{29}$ O UNIVERSAL. Ouro Preto, n. 614, 01 de junho de 1831.

${ }^{30}$ ASTRO de Minas, n. 683, op. cit.

${ }^{31} \mathrm{Cf}$. OZOUF-MARIGNIER, Marie-Vic. La formation des départements: la représentation du territoire français à la fin du 18e siècle. $2^{a}$ ed. Paris: Ed. De l'École des Hautes Études en Sciences Sociales, 1992; SILVA, Ana Cristina Nogueira da, op. cit.

${ }^{32}$ Durante as discussões sobre a necessidade de uma nova organização geral da província em 1825, o conselheiro de governo Bernardo Pereira de Vasconcellos também sugeriu que, em virtude da adoção do critério da concentração populacional e da consequente possibilidade de constituição de municípios com grande extensão territorial, as câmaras deveriam delegar a autoridade municipal de modo que ela fosse exercida em todo o termo, e não apenas na cabeça. Por isso, propôs uma subdivisão dos municípios em distritos de 200 a 300 fogos, e que em cada um deles houvessem delegados das câmaras municipais (Cf. APM. SP 33, op. cit.)
} 
levantado pelo coronel E. G. Barão d'Eschwege e revisto e ampliado pelo secretário de governo Luiz Maria da Silva Pinto, o projeto propunha a criação de trinta novas vilas, redefinindo significativamente a organização interna da província de Minas Gerais. ${ }^{33}$

A efetivação dessas transformações na organização político-administrativa territorial da província não seria, no entanto, uma tarefa fácil. Como indicava o secretário de governo Luiz Maria da Silva Pinto, faltavam exatas notícias topográficas e hidrográficas para o conhecimento dos melhores limites naturais a serem adotados, das latitudes que melhor atenderiam a comodidade pública e os dados sobre a população de diferentes localidades eram imprecisos ou mesmo inexistentes. ${ }^{34}$

Não faltaram iniciativas para obtenção de saberes mais precisos sobre esse território - e sobre os recursos humanos e materiais nele existentes - que poderiam auxiliar, também, na instituição e formulação das bases para uma nova organização territorial interna da província. O Presidente e Conselho de Governo exigiam, em 1825, informações das câmaras municipais sobre a extensão dos termos, distritos e paróquias, número de moradores, sexo e estado, ocupação de seus terrenos por sesmarias, a cultura agrícola praticada, etc. ${ }^{35}$ Já em 1831, mandavam que os juízes de paz fizessem, em seus distritos, uma relação dos habitantes, especificando suas "qualidades", condições, idades, estado e ocupações. ${ }^{36}$ O Conselho Geral, por seu turno, também em 1831, elaborou uma proposta, convertida em decreto, para que na província houvesse dois oficiais de engenharia encarregados de levantarem plantas e mapas topográficos das estradas da província. ${ }^{37}$

Todavia, no que toca à reorganização das circunscrições municipais, apesar daquele ensaio inicial, muitas das propostas elaboradas pelos Presidentes em Conselho de Governo e pelo Conselho Geral de Minas Gerais se pautariam em alegações mais genéricas, como a de que as localidades consideradas eram lugares que atendiam aos "requisitos necessários para que sejam eretos em Vilas". ${ }^{38}$

\footnotetext{
${ }^{33} \mathrm{O}$ projeto, que também criava novos Julgados e 40 freguesias na proporção de 4 mil para 6 mil almas, foi encaminhado ao governo imperial apenas em 1830. Podem ser consultados em CARVALHO, Téofilo Feu de. Comarcas e termos: creações, supressões, restaurações, incorporações e desmembramentos de comarcas e termos em Minas Gerais, 1700-1915. Belo Horizonte: Imprensa Oficial, 1922.

${ }^{34}$ Apud ibidem. p. 97-98.

${ }^{35}$ MINAS GERAIS. Diários do Conselho de Governo da Província de Minas Gerais de 1825, op. cit., n. 03.

${ }^{36}$ APM. SP. Registro de atos do Conselho do Governo relativos ao Governo das Armas e os Índios, SP 64.

${ }^{37}$ APM. CGP 04, op. cit.

${ }^{38}$ Ibidem.
} 
E, nessa direção, os planeamentos seriam muitos. O Conselho Geral apresentou, em 1831, uma proposta para criação de nove novas vilas na província, em 1832, outra, que criava vinte e cinco municipalidades e, entre 1833 e 1834, sugeriu quatro criações específicas, ao passo que o Presidente e Conselho de Governo, para além do projeto de 1825, que demandava a criação de trinta novas vilas, resolveu, em 1833, pela criação de duas e pela extinção de uma e propôs, em 1834, a criação de outras dez. Entre todas essas proposições foram concretizadas apenas doze criações e uma supressão, o que, no entanto,

Mapa 1 - Vilas criadas em Minas Gerais (1825-1834)

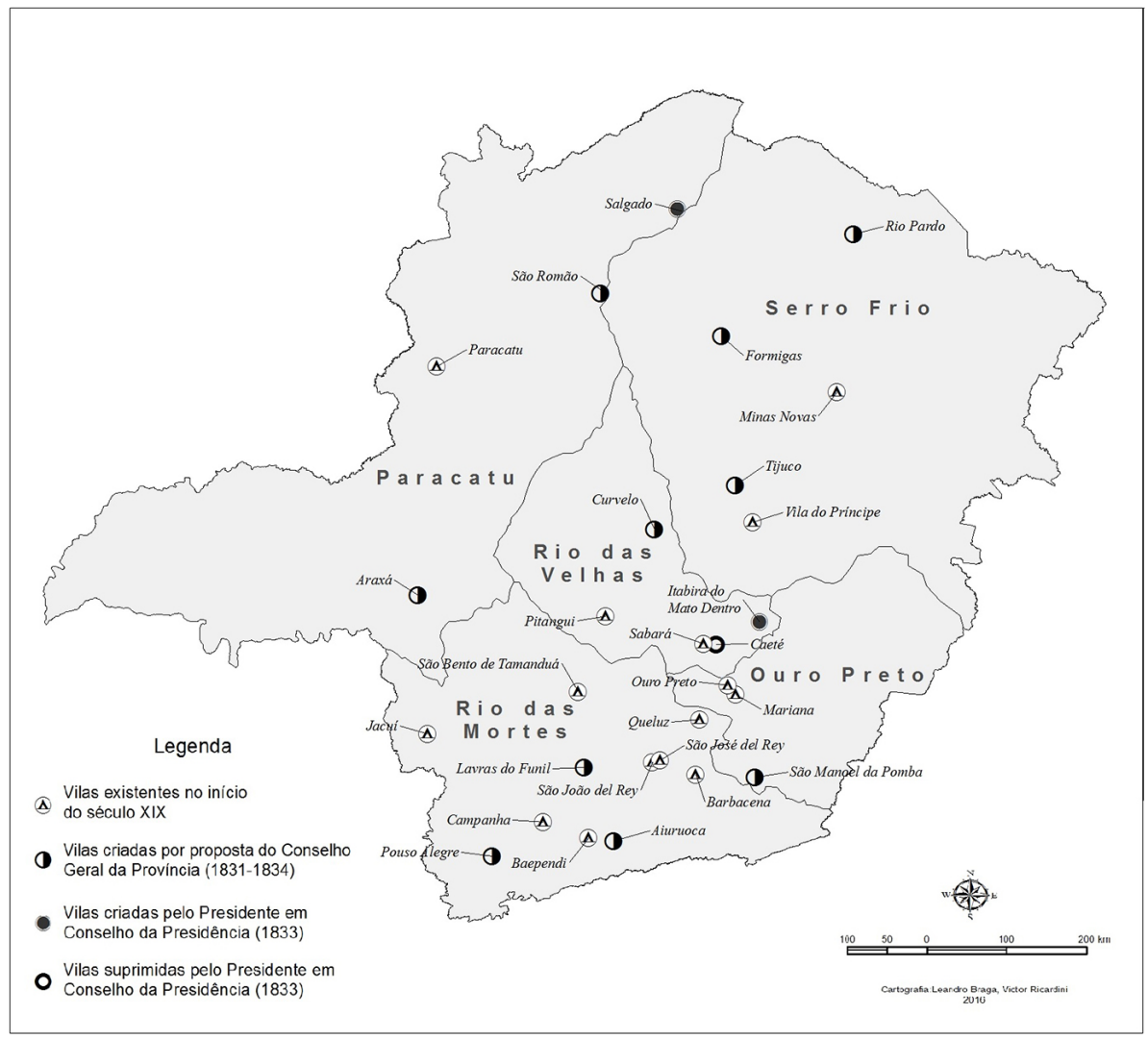

Fontes: APM. CGP 04, op. cit.; APM. CGP. Registro das propostas e pareceres do Conselho Geral da Província, CGP 07; APM. SP. Registro de pareceres do Conselho do Governo, SP 93. 
quase duplicou a quantia de municipalidades compreendidas no território de Minas Gerais.

Embora houvesse uma significativa coincidência entre as localidades consideradas para serem alçadas à condição de vila nas propostas apresentadas pelas instituições provinciais mineiras e uma patente preocupação com a dispersão espacial, a centralidade das sedes e a concentração populacional - que se somavam a outras, como a consolidação das fronteiras da província - a generalidade que as sustentava abria margens para utilização de critérios mais subjetivos, vinculados, por exemplo, às negociações travadas entre as elites políticas dentro e fora da província. Não menos significativo, ela potencializava a emergência de tensões oriundas de insatisfações quanto às circunscrições, sejam elas propostas ou, inversamente, preteridas.

\section{Um duelo de palavras}

A temática da organização político-administrativa do território, condicionante de diferentes dimensões da realidade na vida cotidiana das pessoas ${ }^{39}$, ocupava grande parcela das demandas apresentadas pela sociedade pela via peticionária ao Presidente em Conselho de Governo e ao Conselho Geral na província de Minas Gerais. Solicitações sobre semelhante matéria não eram novidades, já que figuravam, desde muito, como recorrentes objetos de lamentos e pedidos encaminhados à Coroa e seus agentes. Contudo, seus repertórios, nessa nova conjuntura política, continham alterações significativas, sobretudo, do ponto de vista dos argumentários empregados, vinculados cada vez mais a princípios valorativos tidos por coerentes junto às proposições de "racionalização" do governo, difundidos pela imprensa periódica e amplamente propagados pelas instituições provinciais mineiras.

Estas, por seu turno, querendo atender como lhes cumpria "as muitas representações dos Povos desta vasta província”, valiam-se dessas petições como baluartes que assegurariam a necessidade (e a urgência) de uma nova organização interna do território mineiro. Além disso, muitas das demandas sobre o assunto remetidas pela via peticionária foram consideradas na formulação das propostas elaboradas pelo Presidente em Conselho de Governo ou pelo Conselho Geral, como é o caso daquelas dos habitantes de Araxá, Carmo do Pouso Alto, São Domingos de Tucoiós, Piumhi, Uberaba, entre outros.

${ }^{39} \mathrm{Cf}$. SILVA, Ana Cristina Nogueira da, op. cit. 
Não obstante, se, por um lado, muitas das povoações "que tanto tem direito a seu engrandecimento" 40 ansiavam pelas mudanças na organização territorial aventadas pelas instituições provinciais mineiras, por outro, essas alterações também seriam uma constante fonte de tensões no interior da província.

De fato, os protestos às criações propostas pelo Presidente em Conselho de Governo e pelo Conselho Geral de Minas Gerais fizeram-se sentir, em maior ou menor grau, em diferentes momentos, e envolviam, muitas vezes de forma simultânea, desde as diferentes concepções sobre o território até as disputas travadas entre as elites intraprovinciais, ocasionando, em determinadas ocasiões, sérios conflitos.

Como já ocorria em debates travados na América Portuguesa sobre a criação de novas vilas, os argumentos utilizados nessas contestações centravam-se, em geral, nas "qualidades" - históricas, físicas e dos habitantes - do concelho que tinha seu território desmembrado, nos inconvenientes que uma alteração em seus limites acarretaria e na incapacidade das povoações pretendidas de atuarem como sedes municipais. Entre outros motivos, alegava-se, por exemplo, a antiguidade e os serviços prestados pela municipalidade, a existência de uma estrutura física adequada, a "injusta" redução dos provimentos dos ofícios de justiça e das rendas municipais; e, em oposição, do ponto de vista das novas câmaras, a falta de "homens probos" para ocuparem os cargos ou que aceitassem as serventias dos novos ofícios, a insuficiência de recursos para feitura de obras necessárias a uma sede de concelho, etc. ${ }^{41}$.

Os maiores embates sobre o assunto, no entanto, ocorreram no ano de 1833, em um conturbado contexto político para a província de Minas Gerais (e para o Império), e vincularam-se, diretamente, às controvérsias em torno da implementação do Código de Processo Criminal.

$\mathrm{Na}$ ordem do dia, numa conjuntura de radicalização política marcada, desde a abdicação de D. Pedro I, pela intensificação dos conflitos políticos e sociais em diferentes províncias e localidades do Império ${ }^{42}$, estava a imple-

\footnotetext{
${ }^{40}$ Como destacava o secretário de governo Luiz Maria da Silva Pinto. Apud CARVALHO, Téofilo Feu de, op. cit. p. 97-98.

${ }^{41}$ Sobre os argumentários utilizados na hierarquização do território na América Portuguesa no Antigo Regime, ver: FONSECA, Cláudia Damasceno, op. cit. É preciso reforçar, nessa direção, que esses repertórios continuariam a ser importantes fatores de legitimação que, contudo, conviveriam (e mesmo concorreriam) com outros, associados, nomeadamente, às pretensões mais cartesianas de "racionalização" e "regulamentação" das divisões territoriais.

${ }^{42} \mathrm{~A}$ conjuntura também foi de radicalização política no interior da província de Minas Gerais. Propagavamse uma série de boatos de ameaças a ordem estabelecida, as publicações e embates travados na imprensa
} 
mentação da nova organização judiciária, que fora corporificada em 1832 com a aprovação do Código de Processo Criminal. Dentre outras coisas, a lei de 29 de novembro de 1832 e o decreto de 13 de dezembro de 1832, que dava instruções para sua execução, determinavam que o governo na Corte e os Presidentes em Conselho de Governo nas províncias fariam o "quanto antes a nova divisão de termos e comarcas proporcionada, quanto for possível, a concentração, dispersão, e necessidade dos habitantes, pondo logo em execução essa divisão, e participando ao Corpo Legislativo para última aprovação". ${ }^{43}$

Em Minas Gerais, as discussões sobre a execução do Código do Processo tiveram início em março de 1833. O conselheiro de governo Bernardo Pereira de Vasconcellos, também vice-presidente da província ${ }^{44}$, foi o encarregado de elaborar um parecer sobre a nova divisão dos termos e comarcas mineiros, apresentando seu voto em 16 de março. Na sessão subsequente do Conselho de Governo, em 18 de março, foram debatidas e votadas as nomeações e realocações de magistrados para ocuparem os lugares de juízes de direito, também como previsto pelo Código. ${ }^{45}$

Contudo, os trabalhos do Presidente e Conselho de Governo foram interrompidos poucos dias depois com a eclosão, em Ouro Preto, da "Revolta do Ano da Fumaça", movimento que teve como epicentro o governo da província. Aproveitando-se da ausência do presidente Manoel Ignácio de Mello e Souza, os revoltosos exigiram sua demissão e a expulsão dos conselheiros de governo Bernardo Pereira de Vasconcellos e José Bento Leite Ferreira de Mello. O tenente-coronel da Guarda Nacional, Manoel Soares do Couto, membro suplente do Conselho de Governo, ao lado dos revoltosos, assumiu o governo da província como o conselheiro mais votado diante da ausência dos imediatos da lista.

O então chamado "partido de Ouro Preto", que buscava amparar seu procedimento nas leis imperiais e reafirmar sua legalidade - e mesmo a necessidade das medidas adotadas para a manutenção da ordem - justificava o movimento com acusações de arbitrariedades e abusos cometidos no governo da província por Manoel Ignácio de Mello e Souza e Bernardo Pereira de

periódica e no meio institucional acentuavam-se e eclodiam motins e revoltas que compreendiam diferentes setores sociais. Cf. GONÇALVES, Andréa Lisly. Estratificação social e mobilizações políticas no processo de formação do Estado Nacional Brasileiro: Minas Gerais, 1831-1835. São Paulo: Hucitec, 2008.

${ }^{43}$ BRASIL. Lei de 29 de novembro de 1832, op. cit.

${ }^{44}$ De acordo com a lei de 20 de outubro de 1823 o conselheiro presidencial que obtivesse o maior número de votos seria o vice-presidente da província.

${ }^{45}$ APM. SP 93, op. cit. 
Vasconcellos. Esses, alijados da capital provincial e instalados como "governo legal” em São João del Rey, por seu turno, identificavam o "governo de Ouro Preto" como "ilegal" e "intruso" e seus apoiadores como partidários dos restauradores ou caramurus. ${ }^{46}$

As discussões sobre a execução do Código do Processo definitivamente contribuíram para o aumento das tensões vivenciadas nesse contexto no interior da província de Minas Gerais, cujas disputas de poder no seio da elite política desembocaram no conflito armado. ${ }^{47}$ As nomeações dos juízes de direito e a reorganização dos termos e comarcas detinham um caráter potencialmente conflitivo, já que alteravam hierarquias, o que poderia favorecer determinados projetos políticos, grupos de poder e espaços em detrimento de outros. Não sem motivos, durante o conflito, tanto o "governo de Ouro Preto" como o "governo de São João del Rey" buscaram impor suas resoluções sobre tais matérias.

No que concerne à nova divisão de termos e comarcas da província, com a vitória de Mello e Souza, Vasconcellos e seus aliados, as proposições que elaboraram - antes e durante o movimento sedicioso - foram mandadas executar sistematicamente em 30 de junho de 1833. Entre elas, uma resolução que, além de estabelecer que a província de Minas Gerais seria dividida em nove comarcas $^{48}$, alterava algumas das circunscrições dos termos da província. Como redefinições mais significativas, criava-se uma vila no Salgado, já proposta em parecer de Vasconcellos de 16 de março de 1833, e erigia-se a essa condição Itabira do Mato Dentro bem como suprimia-se a existência da vila de Caeté, na conformidade de uma decisão tomada pelo Conselho de Governo instalado em São João del Rey na sessão de 20 de maio de $1833 .{ }^{49}$

De modo particularizado, as resoluções de criação de uma vila em Itabira do Mato Dentro (até então compreendida no termo de Caeté) e, principalmente, a de suprimir-se a condição de vila de Caeté, localidade precursora e centro de apoio aos "sediciosos de Ouro Preto", desagradou sobremaneira as elites políticas daquela localidade e seus aliados. Os protestos contra a

\footnotetext{
${ }^{46}$ BARATA, Alexandre Mansur. A revolta do ano da fumaça. Revista do Arquivo Público Mineiro, ano L, no I, jan-jun de 2014; SILVA, Wlamir. Liberais e o Povo: a construção da hegemonia liberal-moderada na província de Minas Gerais (1830-1834). Hucitec: São Paulo, 2009.

${ }^{47}$ Ver: BARATA, Alexandre Mansur, op. cit.

${ }^{48}$ Ouro Preto, Rio das Mortes, Rio das Velhas, Serro Frio, Paracatu, Rio São Francisco, Rio Sapucaí, Rio Paraibuna e Rio Jequitinhonha.

${ }^{49}$ APM. SP. Registro de atas das sessões do Conselho do Governo (Governo de São João Del Rei), SP 100.
} 
medida persistiram após a pacificação da província, constituindo-se como tema central nos debates sobre a anistia (ou não) dos envolvidos.

o Senado do Império seria o cenário onde o embate ganharia forma. Em julho de 1833, sob requerimento do Marquês de Baependi e com amplo apoio dos senadores, foi colocada em questionamento a legalidade, de acordo com o Código do Processo, da resolução do governo provincial mineiro de abolir a existência de uma vila já instalada. ${ }^{50}$

Animadas por denúncias de parte da imprensa periódica de que o Presidente e Conselho mineiro perseguiam a vila de Caeté por nela se delatarem fraudes e subornos que ocorreram nas eleições para deputados ${ }^{51}$, as críticas ao rebaixamento da condição político-administrativa de Caeté, abordada na Câmara Alta em específico, vincular-se-iam diretamente, em seus argumentos, aos acontecimentos em torno da "Sedição de Ouro Preto": a resolução seria fruto (e mesmo a prova) das condutas "arbitrárias" e "despóticas” do Presidente da província de Minas Gerais, Manoel Ignácio de Mello e Souza, e de alguns de seus conselheiros, movidos por sentimentos de "ignóbeis vinganças" ${ }^{52}$ sobre aquela vila.

Nesses termos, o senador mineiro Visconde de Caeté - caracterizado pelos periódicos moderados como simpatizante dos "caramurus" e apoiador do movimento sedicioso de $1833^{53}$ - declarava ser "fato inegável que o Presidente abusou de Poder":

Caeté reconheceu o Governo de Manoel Soares do Couto, depois da deposição de Manoel Ignácio e isto por ser aquele o conselheiro mais votado, e seria indispensável reconhecer um governo, sem o qual tudo seria anarquia [...] eis o delito de Caeté, eis a única causa do castigo que se lhe dá! E como, senhores, deixaremos nós desmoronar um edifício para depois o reedificarmos? [...] Se convém criar uma vila em Itabira, crie-se, embora, mas não se derrube contra a lei a que longos anos o é..$^{54}$

Com ampla repercussão na imprensa periódica do período, as discordâncias sobre a revogação da condição de vila de Caeté, em última instância, promoviam uma inversão da culpabilização pelos "funestos" ocorridos

\footnotetext{
${ }^{50}$ BRASIL. Anaes do Senado do Império do Brazil: terceira sessão da primeira legislatura - 1833. Rio de Janeiro: Imprensa Nacional, 1916. p. 311-312.

${ }^{51}$ O CATÃo. Rio de Janeiro, n. 87, 7 de agosto de 1833.

${ }^{52}$ BRASIL. Anaes do Senado do Império do Brazil, op. cit. p. 351.

${ }^{53} \mathrm{O}$ Visconde de Caeté apresentou no Senado suas justificativas para ter aconselhado a câmara de Sabará a reconhecer Manoel Soares do Couto como vice-presidente da província. Ibidem.

${ }^{54} \mathrm{Ibidem}, \mathrm{p} .348$.
} 
daquele março 1833. À medida que se cogitava a anistia dos envolvidos na revolta, que teriam procedido legalmente em benefício da província, buscava-se responsabilizar Manoel Ignácio de Mello e Souza (com ou sem seu Conselho, a depender do parecer) por atos arbitrários de "semelhante natureza" ${ }^{55}$

A ilegalidade da "injusta" resolução do Presidente em Conselho, nessa perspectiva, era, além do mais, acentuada pelas inúmeras "qualidades" e "virtudes" da vila de Caeté, uma das "mais antigas da província" de um longo histórico de distinção "desde o tempo de Albuquerque". Sua população, composta "de numerosa gente [...] dada ao trabalho, honrada, hospitaleira, reinando nela a fidelidade, bons costumes, e obediência exata as leis [...]", compreendia muitos "cidadãos habilitados para os empregos municipais" e "as pessoas mais gradas do termo, e quiçá da província". ${ }^{57} \mathrm{Seu}$ terreno "ótimo e muito aurífero" 58 e seus arrabaldes "coalhados de gado, encobertos de hortas, jardins, e pomares" ${ }^{59}$ davam suporte a uma boa estrutura, composta de casa de cadeia e câmara, um pelourinho "que é uma coluna muito bem-feita, uma peça rica" ${ }^{60}$ e avenidas e ruas largas e espaçosas, ornadas "de casas, e edifícios, sobressaindo a todos a majestosa Igreja Matriz, a melhor da província [...]". ${ }^{61}$

Recuperando-se um argumentário já empregado nos domínios do Antigo Regime Português por aqueles concelhos que tinham seus territórios ameaçados de desmembramento em virtude da criação de novas vilas, os partidários de Caeté instrumentalizavam tópicas hierarquizadoras do espaço em defesa da manutenção da vila. O periódico “O Catão", publicação atribuída na época ao deputado Montezuma, indagava, nesse sentido:

Quando é que entre nós se tirou o foro de vila a uma Povoação, enriquecida de todos os edifícios, de todos os tribunais, e estabelecimentos relativos aos misteres do Povo, e exercício da pública autoridade? Nunca. Em o tempo do governo colonial nunca se praticou tamanho atentado contra os direitos nacionais; nunca se abusou por um modo tão inaudito do Poder [...]. ${ }^{62}$

\footnotetext{
${ }^{55}$ Ibidem, p. 352.

${ }^{56}$ Ibidem, p. 311-312.

${ }^{57}$ O VERDADEIRO Caramuru. Rio de Janeiro, n. 42, 4 de novembro de 1833.

${ }^{58}$ BRASIL. Anaes do Senado do Império do Brazil, op. cit. p. 311-312.

${ }^{59}$ O VERDADEIRO Caramuru, op. cit.

${ }^{60}$ BRASIL. Anaes do Senado do Império do Brazil, op. cit. p. 311-312.

${ }^{61}$ O VERDADEIRO Caramuru, op. cit.

${ }^{62}$ O CATÃO. Rio de Janeiro, n. 87, 7 de agosto de 1833.
} 
Baseando-se em uma concepção corporativa do território político assentada no princípio teológico-político de sua inalterabilidade ${ }^{63}$, com ares jusnaturalistas, "O Catão" reafirmava a existência de direitos adquiridos pelos Povos quando da criação de uma vila ou cidade, ou seja, dos direitos de cidade, vizinhança ou de cidadão em um sentido antigo, invioláveis senão em razão do maximum civis caput ${ }^{64}$. A vila era aqui entendida como "corpo moral" ou "reunião de cidadãos", que trazia em seu foro "uma verdadeira emancipação política". Numa atualização dos fatores de legitimação do discurso jurídico, para o periódico, tal como na forma da Constituição do Império do Brasil de 1824 , não se podia negar a um cidadão o gozo de seus direitos políticos sem sentença condenatória de um crime, o mesmo não poderia ser feito a respeito de uma vila ou cidade. ${ }^{65}$

Essas contestações, não alheias à progressiva valorização do discurso da racionalização como princípio fundamental para a governação, valiam-se, sobretudo, de justificativas centradas nos direitos históricos e adquiridos e nas notáveis "virtudes" daquela vila, mas não deixavam de indicar, do mesmo modo, a "irracionalidade" da medida, que criaria empecilhos aos "muitos" habitantes dos arraiais e povoações circunvizinhos a Caeté, que, assim, ficariam mais distantes da sede do concelho. E, principalmente, buscava-se denotar o voluntarismo daquela decisão, guiada não pela "razão", mas pelas “paixões políticas". A supressão de Caeté não poderia ser outra coisa senão resultante de arbitrariedades e abusos de poder por parte de Mello e Souza e seu Conselho: "sanha e rancor"66, "ódio e vingança" "foram os únicos sentimentos consultados pelo Mandão" ${ }^{67}$.

Do outro lado, o Presidente e Conselho de Governo de Minas Gerais, e também os periódicos moderados que os apoiavam, insistiriam na legalidade da resolução e nos propósitos de razão e utilidade que a guiavam. A "antiguidade" da vila de Caeté, formada em virtude da extração de ouro e pedras preciosas, não poderia ser um impasse para o rebaixamento de categoria administrativa, já que a divisão do território deveria se basear em critérios de

\footnotetext{
${ }^{63}$ HESPANHA, António Manuel, op. cit. p. 93; FONSECA, Cláudia Damasceno, op. cit. p. 299-328.

${ }_{64}$ "A união de todos os direitos citadinos era condensada em um só nome [...], e esta palavra corresponde àquilo que os antigos romanos chamavam de maximum civis caput. Esses direitos eram políticos e civis. Aqueles consistiam na escolha de seus líderes e no voto nas assembleias; estes na impossibilidade de ser julgado senão pelos próprios concidadãos, pagar apenas os impostos acordados por consenso" [tradução nossa]. MEYER, C. Delle istituzioni giudizziarie in Europa. Napoli: Dai Torchi del Tramater, 1828. p. 16.

${ }^{65}$ O CATÃO, n. 87, op. cit.

${ }^{66} \mathrm{O}$ VERDADEIRO Caramuru, n. 42, op. cit.

${ }^{67}$ O CATÃO, n. 87, op. cit.
} 
concentração populacional - e "comodidade" do maior número de habitantes - e na "dispersão". ${ }^{68}$ Sendo Caeté uma vila em "decadência" e "abandono" e Itabira uma povoação mais central, muito mais populosa e florescente, a resolução havia sido tomada acertadamente pelo Presidente em Conselho, em conformidade com o disposto no Código do Processo.

Nessa direção, os senadores, ao questionarem a legalidade da resolução, teriam agido com imparcialidade, sobretudo considerando-se que outras províncias e mesmo o ex-Ministro da Justiça haviam dado essa mesma inteligência à lei. As críticas, que se revertiam para a própria instituição do Senado, vitalício e composto por nomes escolhidos pelo ex-Imperador, eram de que aquela Casa obrava por "simpatia" ao "partido de Ouro Preto": as acusações feitas ao Presidente e Conselho tinham como objetivo "escurecer a verdade, fechar os olhos a luz da convicção". ${ }^{69}$

$\mathrm{Na}$ falta de uma arbitrariedade que justificasse a Sedição de 1833, a resolução de supressão da vila de Caeté, para os partidários de Mello e Souza, era utilizada pelos revoltosos e seus apoiadores para encontrar "erros ou crimes em sua administração"70 de modo a amparar a anistia dos envolvidos no movimento. Mais que isso, as acusações sobre sua ilegalidade e arbitrariedade seriam movidas pelas vaidades de um senador em específico, o Visconde de Caeté. Nesses termos, o Universal declarava que:

[a ocasião] deu lugar a alguns nobres senadores a entrarem no vasto campo das declarações contra os mineiros amigos da Legalidade, ali se distinguiram muito os Baependis, os Gomides, os Joões Evangelhistas, os Condes de Valença, e sobre todos, o Visconde de Caeté. E quem não reconhecerá neste nobre aristocrata um justo ressentimento por degradarem desta arte o seu feudo? Pois é graça ficar o sr. Visconde sendo do arraial de Caeté em lugar da Vila de Caeté? ${ }^{71}$

As insinuações feitas contra a figura do Visconde de Caeté, que incorporava, em diferentes sentidos, as críticas direcionadas ao Senado e, principalmente, aos sediciosos, coadunava com a narrativa ${ }^{72}$ sustentada por Mello e Souza, Vasconcellos e seus aliados de que o movimento de março de 1833 teria sido realizado por um pequeno grupo de restauradores, "estacionários",

\footnotetext{
${ }^{68}$ O UNIVERSAL. Ouro Preto, n. 916, 16 de agosto de 1833; ASTRO de Minas. São João del Rey, n. 909,10 de setembro de 1833.

${ }^{69}$ O UNIVERSAL. Ouro Preto, n. 923, 2 de setembro de 1833.

${ }^{70}$ ASTRO de Minas, n. 909, op. cit.

${ }^{71}$ O UNIVERSAL, n. 916 , op. cit.

${ }^{72}$ Já destacada por Wlamir Silva. Cf. SILVA, Wlamir, op. cit.
} 
"retrógrados" contrários às "instituições liberais".73 O Visconde de Caeté, "aristocrata", "fidalgo", "nobilíssimo", que se ressentia de perder "seu feudo", o "berço da sua nobreza”, era a própria encarnação dos caramurus, homens "que escutam de perto o seu interesse; e almejam o poderio, a que deveriam aspirar somente ostentando talentos, e virtudes!". ${ }^{74}$

$* * *$

As principais lideranças envolvidas nos "sucessos extraordinários" ocorridos em Ouro Preto, na revolta do Ano da Fumaça, e em Camanducaia, no movimento de autoproclamação à vila, foram acusadas e sentenciadas pelo crime de sedição, mas acabaram sendo anistiadas em 1835. Apenas em 1840, por meio de leis da Assembleia Legislativa da província de Minas Gerais, Caeté teria sua condição de vila restituída e Camanducaia finalmente seria emancipada de Pouso Alegre, logrando aquela ansiada elevação.

De todo modo, em meio a esses movimentos, as decisões político-administrativas tomadas pelas instâncias de poder, assim como as distintas operações discursivas que as sustentavam ou contestavam, subjaziam os conjuntos de valores e modos de pensar presentes naquela sociedade e também as intensas disputas travadas pelas elites políticas mineiras em busca da (re)afirmação de seus poderios, de seus projetos políticos e do controle institucional (e simbólico) dos rumos a serem tomados por suas localidades, pela província de Minas Gerais e mesmo pelo Império do Brasil, sobretudo quando consideramos o território como mediador necessário à viabilização do exercício do poder.

Artigo recebido para publicação em 11/08/2017

Artigo aprovado para publicação 06/11/2017

\footnotetext{
${ }_{73}^{73}$ AP. CGP. Série 3: Documentação Interna, Subsérie 1: Atas (CGP³1), cx. 06. ${ }^{74}$ Ibidem.
} 